\title{
Svetlana Sabrukova \\ Examples of Buddhist Letters from A.M. Pozdneev Archives Collection
}

\begin{abstract}
Buddhist letters represent official documents that were issued by the Dalai Lamas and Panchen Lamas to prominent political or religious figures as a sign of recognition of their achievements. They appeared at the end of the 16th c. when Buddhism was recognized as a state religion among Mongolian peoples. Three copies of such letters have been kept in the A.M. Pozdneev (1851-1920) collection in the Archives of the Orientalists at the Institute of Oriental Manuscripts, RAS. The earliest letter, which was written in Tibetan semi-uncial script and included a translation in the Oirat language, was given by the 5th Panchen Lama (Lobsang ye shes dpal bzang, 1663-1773) to a Torghut Yogochari Tsordji. Two other scrolls were written only in Tibetan semiuncial script and were given by the 13th Dalai Lama (1876-1933) and the 9th Panchen Lama (1883-1937) in 1903 to a Dörbet Lama Ngag dbang sangs rgyas. From a practical point of view, these letters can be seen as certificates of completed education and obtaining a title that enabled the holder to engage in teaching activities. Their language and style have a formal structure and are of scholarly interest to researchers as examples of Buddhist documents.
\end{abstract}

Key words: Buddhist letters, Panchen Lama, text, document, seal

Buddhist letters represent official documents that were issued by the great lamas - the Dalai Lamas and Panchen Lamas - to prominent political or religious figures as an acknowledgment of their achievements. They first appeared at the end of the 16th c. when Buddhism was recognized as a state religion among Mongolian peoples.

As the centers of religious life in Tibet as well as in other Buddhist regions. Monasteries provided education to the sons of Mongolian and Oirat khans and princes. After graduation they were given official letters or certificates from the Dalai Lama and Panchen Lama. Those letters can be seen as certificates of having completed their studies at a Tibetan monastery and obtaining a certain degree that allowed the holder to engage in teaching activities. Such letters are kept in the Pozdneev collection in the Archives of the Orientalists, IOM, RAS, and belonged to the prominent specialist in

(C) Svetlana Sandzhievna Sabrukova, Institute of Oriental Manuscripts, Russian Academy of Sciences 
Mongol studies Aleksei Matveevich Pozdneev (1851-1920). Among its many and varied documents the collection contains a folder with some papers bearing the inscription "Photographs and reprints of Mongolian and Tibetan texts including receipts for having them copied". ${ }^{1}$ Besides the photographs and reprints the folder also contains an invoice and a receipt made out to A.M. Pozdneev for the making of three zinc plate engravings and three photographs dated 1st January 1907 and received from the Office of the Supplier to the Court of His Imperial Majesty, the Company of R. Golike and A. Willborg. He paid a total of 54 roubles and 99 kopecks.

The collection consists of twelve items - three photographs and one printed reproduction for each of the three official letters or certificates issued by the Dalai Lama or the Panchen Lama. The originals appear to be pieces of material bearing images and texts. There is no data about the place where those letters were found.

As we have established, one letter is older than the other two. It is written in Tibetan semi-uncial script and contains a translation into the Oirat language. The copy of this letter shows that at the time the photograph was taken it was in a worse condition than the other two - in several places the material had become worn out and wrinkled therefore both the Tibetan and the Oirat texts cannot be fully reconstructed.

As far as the copies show, the two other letters were preserved quite well. They resemble the letters described by the Mongolian academician Rinchen, which also contain images of Buddhists deities at the top and bottom. "Among the Oirat people of Western Mongolia the librarians of the Gandantegchinlen monastery have found unique documents dating from the time of the Oirat conquest of Tibet and issued to Oirats by the Dalai Lama, the Panchen Erdeni and the Nechung-chojung oracle. They were written in the Tibetan and Kalmyk languages by a skilful calligrapher on pieces of yellow silk: Tibetan - in Tibetan cursive script and Kalmyk — in the Oirat script developed by Zaya Pandita Ogtorguyn Dalai. At the top and the bottom of each letter there are several images of Buddhist deities and stamps with inscriptions in the phags-pa script ${ }^{2}$ belonging to the great lamas who issued those letters". ${ }^{3}$ Unlike the letters described by the academician Rinchen, the text in our letters is written in Tibetan. They are official letters or certificates issued by the 13th Dalai Lama (1876-1933) and the 9th Panchen Lama (1883-1937) to the same person - Ngavan Sangye, a lama

\footnotetext{
${ }_{2}^{1}$ Archives of the Orientalists, IOM, RAS. Fund 44, inv. 1, unit 120.

${ }^{2}$ Phags pa ('phags pa) script named after its creator Drogön Chögyal Phagpa ('gro mgon chos rgyal 'phags pa, 1239-1280). For more details about this script see POPPE 1941, 11-12.

${ }^{3}$ RINCHEN 1966, 65.
} 
from the Tashilhunpo monastery who belonged to a Dörben clan of chief scribes (shog dpon) Tseren Sar-gerel (tshe ring zla-'od). The letters open with a call to northern peoples: to nine Mongolian tribes, four Oirat tribes and seven Khalkha tribes, to khans and their sons, to Buddhist clergy, to great and minor ministers, zaisangs, ${ }^{4}$ monks and laypeople. After that the text says that this person Ngavan Sangye honours the teaching with great respect, makes an effort to understand the wisdom, has finished the complete course of study at the monastery, has been engaged in the translation of sacred scriptures, and has been awarded a title or a position of Chos Rje chief abbot of the monastery (chos rje). ${ }^{5}$ At the end of the letters there is information about the place and the time that they were issued: the first letter was issued in the Dalai Lama's residence, the Norbulingka Palace, in the year of the water rabbit, i.e. 1903, the second letter was issued in the Tashilhunpo Palace - the residence of the Panchen Lama, both were sealed by stamps of the great lamas.

The texts of the letters issued by the Dalai Lama and the Panchen Lamas have a similar structure: they start with an address to all living beings, then introduce the person, state his position in the society, the place he was born, and list his achievements in Buddhist studies. After that, they state a request or a wish addressed to rulers and common people to show this person proper respect. At the end there is a mention of the place and time that the letter was issued.

The most interesting among those three copies is the reproduction of the earliest letter written in two languages, dated the year of the water dog, i.e. 1682, and issued in the Tashilhunpo Palace, the residence of Panchen Lamas by the 5th Panchen Lama Lobsang Yeshe (lobsang ye-shes dpal bzang, 1663-1737). It is an official document at the top of which there is an inscription that the letter was given by the 5th Panchen Lama and sealed with his personal round seal. Comparison of the two parts in parallel languages helped to understand the meaning of both Tibetan and Oirat texts. A major problem was posed by abridged words in the part of the text written in Tibetan cursive script.

The Tibetan word ri ne is a short form from rin chen. In the Oirat text this was translated as erdeni which means "precious". Another shortening is the Tibetan word tham cad "all, together", here the syllable $c a$ was dropped and it became thamd. The word was translated into Oirat with two words bügüder and xamuq that both mean "all".

\footnotetext{
${ }^{4}$ Zaisang, head of a Mongol or Kalmyk clan (BrocKHAUS-EFrON 1894, 145).

${ }^{5}$ PozDnEev 1993, 116.
} 


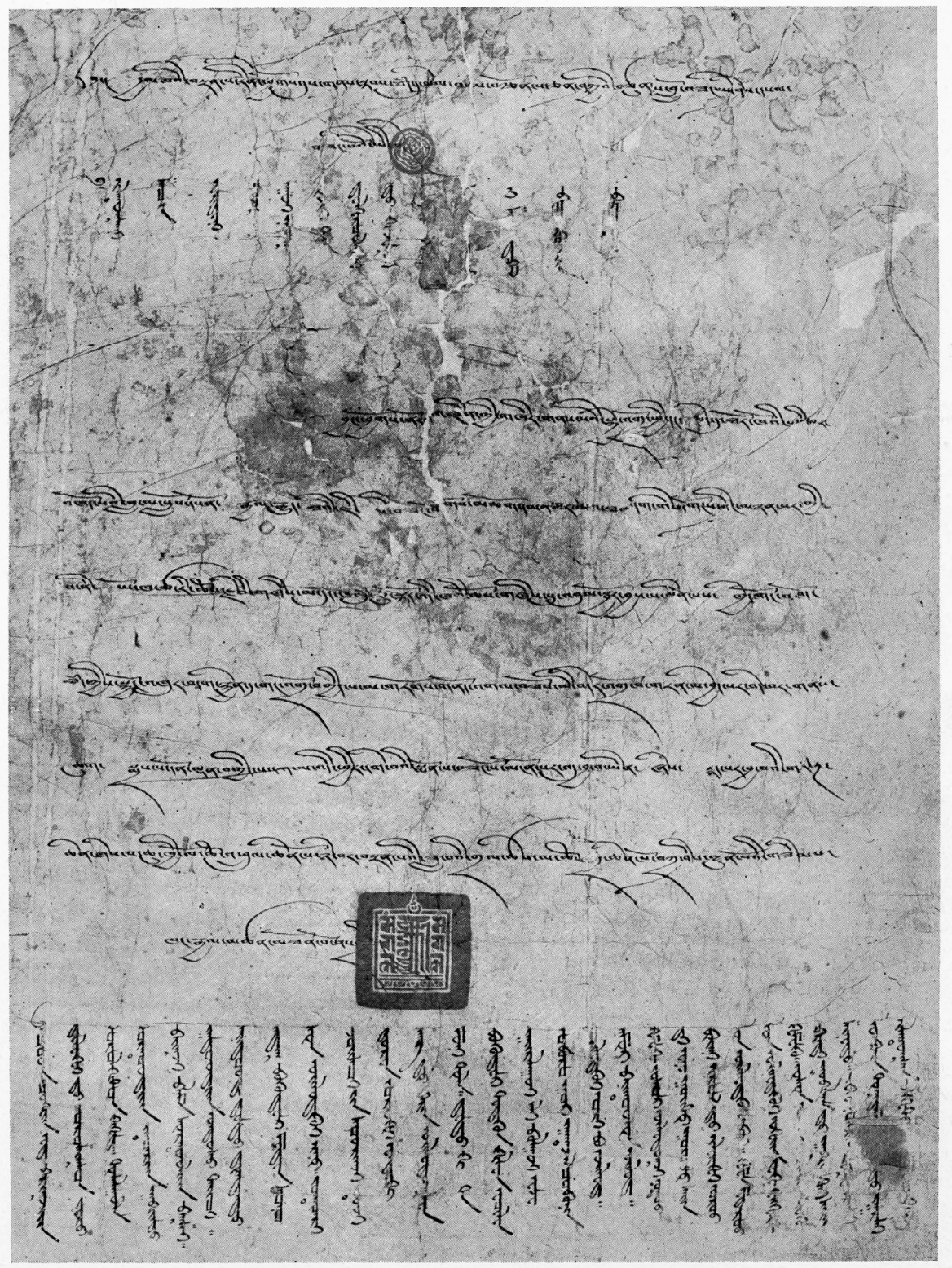


Due to the poor condition of the original letter at the moment the copy was made the transliteration of the Tibetan text presented more problems than the transliteration of the Oirat text, which is a complete translation of the Tibetan original text. Both texts are identical in meaning. The only difference was found at the beginning of the letter in the address to all human beings: the Tibetan text mentions the northern direction (byang phyogs) while the Oirat text translates this phrase as "western direction" (zö̈̈n zügiyin). This might be explained by the historical circumstances at the end of the 17th c. when, after the collapse of the confederation of four Oirat tribes, the Torghut tribe migrated west towards the Irtysh region. For that reason the Oirat translator presumably changed the Tibetan word "northern". Another Tibetan word, nor 'dzin, which belongs to an elevated style and is usually found in poems meaning "the earth", although it can be literally translated as "holder of wealth", was translated into Oirat as ed bariqcit, also one of the words meaning "the earth". The phrase in Tibetan tsho "phrul and in Oirat pradi xubilyān is, as far as we could discover, the name of the first lunar month of the Tibetan calendar which usually begins in February. ${ }^{6}$

For convenience and to help compare the texts, the Tibetan part was divided into eight sections, following the number of lines in this part of the text. The Oirat text was also divided into eight parts correspondingly and they are presented in the following order: Tibetan $(1-8)$, Oirat $(a-h)$, etc. The meaning of the signs used in transliterations: parenthesis with ellipsis $(\ldots)$ the lexeme or grapheme has not been reconstructed; without dots ( ) - has been reconstructed.

\section{Transliteration of the Tibetan and Oirat Texts}

1) rgyal ba'i bstan pa rine phyogs dus gnas skabs thamd du 'phel bsal brtson pa can sha'a kya'i btsun pa blo bzang ye shes dpal

a) ilayuqsani šaèin erdeni züg (cag) axui xamuq učir-tan delgeröülküi-dü kičéqseni šakya-i (...) ni š(ei) dpal

2) bzang po'i (yi ge)

b) bzang poyin bičig:

3) byang phyogs nor 'dzin gyi gzhir gnas pa'i skye 'gro spyi dang ched du thor kho'i sa'i char

c) zö̈̈n zügiyin ed bariqčiyin delekei-dü orošiqson yerü törölkitön kigèd: tuslaxulā toryoudiyin yazariyin

\footnotetext{
${ }^{6}$ BURNEE 2003, 361.
} 
4) 'Khod pa'i bla ma slob dpon rgyal rgyud tha' $i$ ji sa ' $i$ thod (...) mchog dman bar ba mtha' dag (gis)...dgongs shing bnyan par bgyi

d) xabiyādu bayiqči blama suryuuliyin baqši: xādoudiyin ündüsü tayiǰi: sayidoud dédü dundadu adaq bügüdēr meden sonosun üyiledküi

5) ba ni yo kha tsa ri chos rje'i gzhis ma dung kha gsum cu ltar 'di kha'i mos gzhis 'du'bul sbyor byas pa yin pas khye gong (bshod)

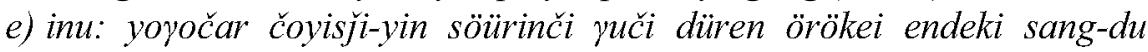
barin üyiledüqsen möni tula: dédü-ki ta

6) thamd kyis skyong 'khur bdag rkyen du gang 'gro bgyid pa ma (gtogs) gnod 'gal (bzos) mi bder 'gro bag tan pa byed par bde bar gnas

f) bügüdēr tedkün kilen ezelen xayiralaxui ali bolxui-ēce öbörö xor xayacal zobonin üyiledküi ori bü ïyiled: amur bayiyoulun üyiled:

7) chug smras pa don ldan bgyid pa (de dag) 'di phyir dge ba'i smon pa bzang po mngon par 'du bya ba yin zhes (shad par) bya ba'i (gsung) rnga

g) kemēbe yosōr üyiledüqči-noyoudi ene xoyitu xoyitu sayin buyani irồ-dü ilerkei oroulun üyiledküi bui: kemēn mederöülün üyiledküi ügeyin yeke (kenggerge) kemēkü:

8) chen zhes pa chu khyi lo cho 'phrul chen po nye bar bstan pa'i zla ba'i gral tshes la chos gra chen po bkra shis lhun po'i gzims khang rgyal mtshan mthon po nas (bris)

h) usun noxoi jiliyin yeke pradi xubilyān-du xabiya-tai sarayin šinedü: yeke (...) taši lunboyin tuqdama (...)-du xarši ilayuqsan belgetü (...) (bičimuii):

\section{English Translation}

This letter [certificate] to a follower of Buddha Shakyamuni the venerable Lobsang Eshe Palzan zealously disseminating the precious teaching of the Glorious [Buddha] in all places to those interested. ${ }^{7}$

Princes and noblemen of high, middle and low ranks, if you want to help all living beings situated in the countries of the northern ${ }^{8}$ [part] of the Earth listen to the honourable tutor of lamas and a native of the Torghut land. Since in the camp of Yogochari Tsordji ${ }^{9}$ thirty full families have made a donation to our monastery [Tashilhunpo]. So you high [rulers] besides taking an effort to protect and acknowledge the achievements, do not commit

\footnotetext{
${ }^{7}$ These words are followed by a small round personal seal of the 5th Panchen Lama.

${ }^{8}$ Western in the Oirat text.

${ }^{9}$ Spiritual name of a lama.
} 
actions [that bring others] only suffering, harm and misery. Always practice good actions [and] live happily. Those who follow the law will definitely acquire good virtues in this life and next rebirths. Such is the meaning of the Big drum of words.

In the year of the water dog of the first Lunar month [following] the instructions, at the beginning of the month contemplating the glorious flag [of the great teaching of the Buddha], in the Tashilhunpo Palace I wrote.

At the end the text is sealed by a square seal with square mangala writings on the left and right sides and a sign of Kalachakra in the middle. N. Poppe in his work about square script wrote that it became obsolete soon after 1351. It is, however, still in linmited use nowadays in Tibet and called hor yig (Mongol script). It is employed on seals (e.g. the Dalai Lama's seal) and in book titles. "Still after many centuries the square script is being used as a seal script. It is known that the inscriptions on the Dalai Lama's seal have been carved in square script up to the present day. Such seals were affixed to letters and documents as a special indication of their importance," the seal described here is concerned, it is the common seal of all Panchen Lamas and is passed on from one Panchen Lama to another, as is evident from the letter of the 9th Panchen Lama (Blo bzang thub bstan chos kyi nyi $m a, 1883-1937)$ which was also sealed with the same seal (at the bottom). At the top of the letter after the image of the Buddhist teacher and the words that the letter was issued by the Panchen Lama, his personal seal is affixed. The letter issued by the 13th Dalai Lama is also sealed with the common seal that is handed on from one Dalai Lama to another. Hence it can be assumed that, besides common seals that passed from one "great" lama to another, the lamas also had their personal seals. The language and the structure of the letters are formal, they are written in an elevated style and are of scholarly interest to researchers as examples of Buddhist documents.

In conclusion it can be stated that such letters were traditionally given to students who had completed their education, received a certain title (in this case Tsordji) that enabled the holder to govern a monastery, to engage in teaching activities and to collect donations for Buddhist temples.

\footnotetext{
${ }^{10}$ Poppe 1941, 15; 23.
} 
84

\section{References}

BURNEe and ENKHTER 2003: Tövd-Mongol ilt ögüülekh neriyn tol' [Tibetan-Mongolian dictionary synonyms]. Ulaanbaatar.

BROCKHAUSE F.A. and EFRON I.A. 1894: Entsiklopedicheskii slovar' [Encyclopaedic dictionary], vol. 12. St. Petersburg: Izdatel'stvo Tipo-Litografiia I.A. Efrona.

LUVSANBALDAN Kh. 1975: Tod üsèg, tü̈nii dursgaluud [Clear script and his written monuments]. Ulaanbaatar: Shinzhlekh Ukhaany Akademiin khevlekh.

Chandra Das. 1988: A Tibetan-English Dictionary. Reprinted from the original edition, Calcutta (1902). Kyoto: Rinsen Book Co.

POZDNEEV A.M. 1993: Ocherki byta buddiiskikh monastyrei i buddiiskogo dukhovenstva $v$ Mongolii v sviazi s otnosheniiami sego poslednego $k$ narodu [Essays on the life of Buddhist monasteries and Buddhist clergy in Mongolia and relations of the latter to the people]. Reprint. Elista: Kalmytskoye knizhnoye izdatelstvo (Nashe Naslediye).

PopPE N.N. 1941: Kvadratnaia pis 'mennost' [The square script]. Moscow-Leningrad: Izdatel'stvo Akademii Nauk SSSR.

RINCHEN 1966: Oiratskie perevody s kitaiskogo [Oirat translations from Chinese]. Rocznik Orientalistyczny 30(1), 59-73 (offprint).

SHAStinA N.P. 2003: “A.M. Pozdneev". Mongolica 6, 7-18. 